\section{Jasna Jovanov}

Spomen-zbirka Pavla Beljanskog, Novi Sad, Srbija

Prethodno priopćenje / Preliminary communication UDK / UDC: 7.036(497.113)"1924/1925"

18. 6. 2014.

\title{
Izložbe Grupe nezavisnih umjetnika u Vojvodini od 1924. do 1925.
}

Ključne riječi: umjetničke grupe, Grupa nezavisnih umjetnika, izložbe, Vojvodina Keywords: artist groups, Independent Artists Group, exhibitions, Vojvodina

Grupa nezavisnih umjetnika bila je aktiona između 1921. i 1927. godine. Aktionost grupe uglavnom se ogledala u izložbenim nastupima u okviru različitih grupnih izložbi ili u vidu samostalnih nastupa većeg dijela članstva. Karakteristično za ovu grupu jest inzistiranje na izlaganju u naseljima izvan većih kulturnih centara Kraljevine Srba, Hrvata i Slovenaca i poslije Kraljevine Jugoslavije, posebno u Hrvatskoj i Vojvodini. Tijekom 1924. i 1925. godine grupa je u dva navrata priredila seriju izložbi, prvo u Novom Sadu i Somboru, a potom u Starom i Novom Bečeju, Senti, Velikoj Kikindi (Kikinda) i Velikom Bečkereku (Zrenjanin). Autorica ovog teksta nastojat će utvrditi što je dovelo do organiziranja izložbi upravo u ovim mjestima, objasniti značenje izložbi $u$ kontekstu suvremene umjetnosti $i$ osvrnuti se na njihovu recepciju u javnosti. Također će se osvrnuti $i$ na ostale nastupe grupe u Novom Sadu i Beogradu, kao i na izvjesne pojedinačne aktivnosti nekih članova koje izlaze iz domene njezina rada, ali imaju stanovitog utjecaja na događaje koje obuhvaća tema rada, kao i na kulturne veze samog razdoblja.

Između dva svjetska rata u Kraljevini Jugoslaviji aktivan je iznimno velik broj umjetničkih grupa. Razlikovale su se po brojnosti pripadnika, programima, načinu manifestiranja ideja i dužini trajanja; uglavnom im je djelatnost bila vezana uz jednu regiju ili umjetnički centar, dok je manji broj bio orijentiran na širi prostor i izvan granica zemlje. Najviše je članova (59) imao i najdulje trajao Oblik aktivan od 1926. do 1939. godine, ${ }^{1}$ sa 16 izložbi u Novom Sadu, Beogradu, Zagrebu, Ljubljani, Sarajevu, Skoplju i Splitu, kao i u Pragu, Plovdivu, Sofiji i Solunu. Manje članstvo, ali intenzivnu izlagačku aktivnost imala je grupa koja je najčešće izlagala u manjim kulturnim sredinama: riječ je o Grupi nezavisnih umjetnika, aktivnoj između studenoga 1921., kada je održala prvu izložbu u Karlovcu, i 1927., kada se pojavljuje na VI. jugoslovenskoj umetničkoj izložbi u Novom Sadu. ${ }^{2}$ Osim spomenutih devet nastupa u Beogradu i Vojvodini, održano je šest izložbi u Karlovcu, Splitu, Koprivnici, Sisku i Varaždinu. Tijekom 1924. i 1925. grupa je u dva navrata priredila seriju izložbi u Vojvodini, prvo u Novom Sadu i Somboru, a potom u Starom i Novom Bečeju, Senti, Velikoj Kikindi (Kikinda) i Velikom Bečkereku (Zrenjanin). Dvojica članova grupe, Jerolim Miše i Marin Studin, u listopadu 1924. godine, u ime cjelokupnog članstva, nakon izložbe u Splitu obratili su se javnosti s objašnjenjem o suštini njihova rada: »U ovim teškim danima razračunavanja, ako nitko a to naša umjetnost upućena je da strši iznad svih političkih programa i da na nju ima jednako pravo svaki pojedinac ove zemlje. Naš put, kako nas je doveo u Zagreb, Novi Sad, Sombor, Split, tako će nas voditi dalje u Suboticu, Beograd, Skoplje. Mi za našu nezavisnu grupu tražimo samo talente i ljude rođene u našoj zemlji, i jedini je naš cilj da nam izložbe budu ozbiljne i valjane. $\aleph^{3}$ Ovakvo obraćanje javnosti bilo je potaknuto politički obojenim raspravama koje su pratile splitsku izložbu i koje su kulminirale u tekstu Hrvatstvo i umjetnost objavljenom u Hrvatskoj riječi, ${ }^{4}$ novinama koje su inače s iznimnom pozornošću pratile cjelokupan tijek 
izložbe. S tim u vezi treba spomenuti opasku o činjenici kako je hrvatski tisak uglavnom isticao hrvatsko, dok je u Vojvodini naglašavano jugoslavensko opredjeljenje grupe. ${ }^{5}$

Iz široko postavljenog koncepta kao zajednički se izdvaja "negativan stav prema pojavama i stremljenjima (ponajviše u odnosu prema Proljetnom salonu)« koje treba shvaćati »kao svojevrsno programsko određenje $\aleph^{6}$ koje rad grupe usmjerava prema "užim afinitetima « ${ }^{7} \mathrm{i}$ istodobno suprotstavlja aktivnostima čija "platforma je vremenom postala preširoka «. ${ }^{8} \mathrm{U}$ tom smislu je kao datum početka njezina rada utvrđena 1923. godina, kada dolazi do raskola s Proljetnim salonom i tako je zapravo vrijeme njezina osnivanja pomaknuto za dvije godine. Tomu je doprinijelo i pisanje jednog njezina pripadnika, Ljube Babića, koji u knjizi Umjetnost kod Hrvata o vremenu kada je grupa bila najaktivnija piše »da se ništa značajno nije dogodilo od 1918. do 1925. «" Babić će poslije bilježiti i druge neutemeljene podatke, uglavnom potom interpretirane bez provjere. Jedan od njih je, svakako, i tvrdnja o izložbi grupe u Muzeju za umjetnost i obrt 1923. koja se, prema Babiću, poklapa s vremenom osnivanja grupe. ${ }^{10}$

Među kritičkim opaskama koje je grupa uputila Proljetnom salonu nalazi se i ona koja se odnosi na odsutnost osobne koncepcije, što kreativni čin svodi na puko savladavanje likovnog materijala. Primijenjena na cjelokupan opus grupe, ova primjedba upućuje na jedinstveno opredjeljenje za osnovne postulate modernosti prikazane u naglašenoj individualnosti, podršci ideji kozmopolitizma kao i svojevrsnoj vizualnoj zrelosti koja »vodi u evropsku umjetničku zajednicu«, kako dopisnik zagrebačkoga Jutarnjeg lista citira dio manifesta grupe objavljenog pod nazivom Nezavisna grupa u listu Hrvatska riječ. ${ }^{11}$

Najveću zanimljivost u programskoj orijentaciji grupe čini njezina spremnost da se predstavi u manjim mjestima, ciklusom izložbi, od kojih, nažalost, mnoge nisu ostavile pisanog traga. Novija su razmatranja pokazala kako je u osnivanju grupe, kao i u kreiranju njezina koncepta i poticanja organizacije putujućih izložbi najvjerojatnije.presudnu ulogu odigrao Jerolim Miše. ${ }^{12} \mathrm{U}$ njegovim likovnim kritikama u razdoblju djelovanja u Brodu (Slavonski Brod) prisutna je snažna frustracija zbog ograničenja kulturnog života i uvjeta umjetničkog djelovanja u provinciji, što dovodi do nastojanja da se kulturni nivo provincije unaprijedi. Pored aktivnog sudjelovanja u kulturnom životu Broda, Miše se oko 1920. godine, potaknut idejama postrevolucionarne Rusije, u tekstovima zalaže za "organiziranje grupe koja bi unaprijedila provinciju: `Hoće li nas biti jedna grupa u provinciji, koja će otvorene nutarnjosti uzajamno, savjesnim putem ići višim ciljevima, daleko od varoških reklama i hirova centruma, jedna grupa dobronamjernih ljudi, s ponosom savjesnih radnika, nezadovoljnih jer svojih, neka nas bude (...) Vidimo najbolje u najnovije vrijeme kako je Rusija shvatila važnost djelovanja u provinciji. Oni udesiše želje- zničke vozove s izložbama, štamparijama, kinematografima, radiotelegrafskim postajama i idu u provinciju od mjesta do mjesta da odgajaju masu s biranim stvarimar." Neposredno nakon objavljivanja Mišinih tekstova organizirane su i prve putujuće izložbe grupe (Koprivnica, Sisak, Varaždin i Karlovac, 1921.), što se pokazalo veoma značajnim $» z a$ podizanje likovne kulture u Hrvatskoj izvan Zagreba«, kao i da su izložbe »imale značajan likovni, edukacijski i općenito kulturni učinak za provincijska središta ${ }^{13}$ na osnovi čega Ana Šeparović donosi zaključak kako je upravo Miše bio i subjektivno motiviran da se zauzme za ideju »o umjetničkom obogaćivanju provincije «. ${ }^{14}$ Ova autorica razmatra Mišu i kao mogućeg autora svojevrsnog manifesta grupe, objavljenog u prilogu Ars Croatica u časopisu Hrvatska riječ u povodu izložbe skupine 1924. u Splitu. ${ }^{15}$ Obrazloženje za svoje tvrdnje nalazi u jezičnoj i sadržajnoj usporedbi ovog i drugih Mišinih tekstova, poput prisutnosti vitalističkih principa »bitne ljepote stvarne životne ekspresije«, individualizirane kreativnosti i potrebe da autor odbaci »razne kanone nepogrešivih tehničkih trikova«. Miše je također, zajedno sa Studinom, potpisnik teksta Nezavisna grupa, čiji se dijelovi pojavljuju u spomenutom manifestu. Kao "misao vodilja većine Mišinih likovnih kritika prve polovine 1920ih « ističe se i komponenta "savjesnosti i ozbiljnosti«, isticanje kako umjetnik mora sam proći težak put »svladavajući savjesno razne tehničke formalnosti«, te prigovor mladim autorima da nemaju »likovne savjesti ${ }^{16}{ }^{1}$ Kao pozitivan primjer ističe Petra Dobrovića, za kojeg »konstatira da se on razvija organski, savjesno produbljujući svoj materijal. «17 Osim mnogih dokaza da je Miše bio jedan od idejnih vođa skupine, podrška slikarstvu Petra Dobrovića u Književnoj republici iz 1924. godine upućuje na moguće prijateljstvo i kreativnu razmjenu između dvojice umjetnika, kao i širenje izložbenih itinerera na Vojvodinu, konkretno na Novi Sad i Sombor. Dobrović početkom 1924. godine prikazuje svoje radove na Izložbi beogradskih slikara i vajara, a potom, u listopadu, zajedno s Brankom Popovićem u praškom salonu »Manes«. Kao profesor Umjetničke škole u Beogradu (1923.-1925.) živi na relaciji Beograd-Novi Sad. Suradnik aktivističkih mađarskih te različitih dnevnih novina i sudionik u pobuni novosadskog puka u Pečuhu 1918., kao i jedan od utemeljitelja i predsjednik izvršnog komiteta kratkotrajne Baranjsko-Bajske Srpsko-Mađarske Republike, 1921. godine, posljednji put izlaže na Proljetnom salonu, a nakon neuspjele diplomatske misije u Srbiji konačno napušta Mađarsku i prelazi u Beograd. Dobrović se također nalazio i među izlagačima na $V$. jugoslovenskoj umetničkoj $i z l o z ̌ b i$ u Beogradu 1922. godine, ${ }^{18}$ kada je nastupio, kao i pripadnici Grupe nezavisnih umjetnika, u okviru postava Proljetnog salona. Njihov nastup u selekciji Salona, bez spomena o otpadničkom statusu i novoosnovanoj grupi, gdje izlažu Frano Kršinić, Ivan Meštrović, Ljubo Babić, Jerolim Miše, Zlatko Šulentić, Marin Studin, Vladimir Varlaj i Joza 


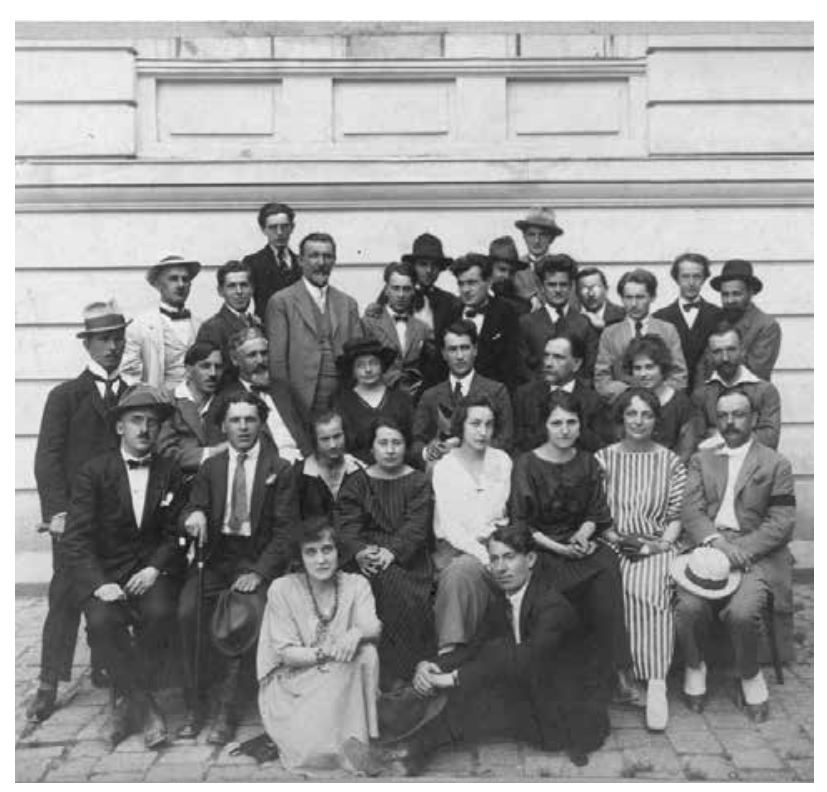

1. Sudionici V. jugoslovenske umetničke izložbe u Beogradu, 1922. (foto: Spomen-zbirka Pavla Beljanskog, Novi Sad) / Participants of the $5^{\text {th }}$ Yugoslav Art Exhibition in Belgrade, 1922 (photo: The Pavle Beljanski Memorial Collection, Novi Sad)

Kljaković, ${ }^{19}$ stvorio je pogrešan dojam da su njihova imena $\mathrm{u}$ katalogu izostavljena. ${ }^{20} \mathrm{Na}$ grupnoj fotografiji snimljenoj tijekom trajanja izložbe (sl. 1), ${ }^{21}$ nalazimo i neke od njih: Kršinića i Mišu, ${ }^{22}$ kao i Vladimira Becića koji tada izlaže s Udruženjem umjetnika, Sarajevo. ${ }^{23} \mathrm{Za}$ razliku od kataloga gdje Nezavisni nisu bili posebno istaknuti, kritičar Momčilo Selesković ih izdvaja iz konteksta Proljetnog salona kao zasebnu izlagačku cjelinu, nazivajući ih "grupa slobodnih«, ali izbjegava izjašnjavanje o njihovim vrijednostima kao i da komentira »radove umetnika koje čovek vidi prvi put, ako su uz to zastupljeni jedva s jednom ili dve slike. ${ }^{24} \mathrm{U}$ ovako neodređenom komentaru istinita je činjenica da su radovi pripadnika grupe bili malobrojni (izložili su jedan ili dva rada), osim kada je riječ o Frani Kršiniću koji je nastupio sa šest skulptura. Kritičar Todor Manojlović iz konteksta izvlači nekoliko imena, kao što su »Ljuba Babić sa svojim efikasnim Raspećem. Od Zlatka Šulentića nalazimo onaj divni, tako toplo i delikatno naslikani portre Moj otac, pored jednog Prečanina dobrovoljca, čija je neznatnost u takvom susedstvu dvostruko osetna. Još je neznatniji, lošiji Portre Ujevića od Jerolima Miša. « ${ }^{25}$ Više naklonosti, posebno kada je su u pitanju »dobro organizovano Raspeće Ljube Babića», ili Mišin nastup na izložbi, pokazat će kritičar Vremena Emil Nadvornik: »Pristalica naprednih umetničkih težnji iz prve decenije dvadesetog veka, savremenik Medulića i njegov kritički oslonac, Jerolim Miše, prvi put u Beogradu 1922. godine učestvuje na jugoslovenskoj umetničkoj smotri. Njegova slika, portret Tina Ujevića, bila je dostojan psihološki lik ovog hrvatskog pesnika. «"

\section{Novi Sad i Sombor, 1924.}

U Magistratu u Novom Sadu, u nedjelju 25. svibnja 1924. godine otvorena je izložba sedmorice hrvatskih autora, pripadnika Grupe nezavisnih umjetnika. Trajala je vrlo kratko, do petka, 29. svibnja; nije imala katalog, niti je, do sada, bilo moguće pronaći arhivske dokumente koji bi svjedočili o neposrednim organizatorima ovog događaja. Iz raznovrsnih napisa u novosadskom, beogradskom i zagrebačkom tisku, utvrđeni su broj eksponata i nazivi djela izloženih radova. Za kritičara novosadske Zastave ${ }^{27}$ imena autora su "dobro poznata i od ranije iz Proletnog i Ulrihovog salona u Zagrebu, a naročito sa $\mathrm{V}$ velike jug. izložbe. « Od ukupno 86 izloženih radova, Ljubo Babić se predstavio novosadskoj publici sa 13 slika s venecijanskim motivima, otprije poznatima autoru članka, a redni brojevi koje on navodi (br. 10, Sa Lida; br. 13, Scuola San Marco; br. 8a, Autoportret) govore nam da je ipak postojao, ako ne katalog, onda bar pisaćom mašnom napisan popis. Jozo Kljaković predstavljen je kao jedan od najboljih "naših « crtača, slikar koji je prije Prvoga svjetskog rata radio zajedno s Miroslavom Kraljevićem i čije su slike "rađene solidno sa mnogo razumevanja i izvrsno komponovane«. Izložio ih je ukupno 10, među kojima se ističu Pastir i Satir i Nimfa, slika koju je izlagao i dvije godine ranije u Beogradu. Dvanaest izloženih portreta Jerolima Miše predstavljaju potvrdu njegova renomea solidnog umjetnika i dobrog portretista, a najbolji primjer za to predstavlja Dama (br. 39). Zlatko Šulentić se predstavio najvećim brojem radova (21), većinom impresija s putovanja po Španjolskoj i sjevernoj Africi. Kao najmanje poznat, jedan od najboljih pejzažista, predstavljen je Vladimir Varlaj koji je izložio 15 radova, podjednako dobrih slika, »sa mnogo svetlih boja«, što je autora članka nagnalo na prognozu da će one svakako ukrasiti novosadske salone. Marin Studin najavljen je kao stanovnik Pariza i umjetnik koji »već nekoliko godina uživa glas najtalentovanijeg vajara, pa je to nesumnjivo izloženim radovima i dokazao.«Studin je izložio četiri rada, a Frano Kršinić 11 skulptura koje odražavaju »jak individualni talenat i dobro poznavanje tehnike«. U svim prikazima koji su pratili izložbu, autori nastoje sa što više informacija predstaviti izlagače, zadržavajući se na nabrajanju radova i isticanju pojedinih slika i kratkim biografskim komentarima, kao što je to slučaj s osvrtima u novosadskim dnevnim listovima Délbácska, Jedinstvo ${ }^{28}$ ili Vidovdan. ${ }^{29} \mathrm{U}$ već spomenutom broju Zastave, na istoj stranici gdje i prikaz izložbe, objavljena je i poduža vijest o njezinu otvaranju. Po zatvaranju novosadske i somborske izložbe, u zagrebačkom Obzoru objavljen je osvrt ${ }^{30}$ koji govori o iznimnom uspjehu izložbi koje je vidjelo 4000 posjetitelja, kao i o otkupu 22 rada. Isto tako, u ovom su osvrtu citirani tekstovi iz Zastave i Vidovdana, a spomenute su i "pohvalne kritike Jedinstva i Délbácske«. Mada je kritički aparat primijenjen u ovim 
prikazima prilično stereotipan i uglavnom zasnovan na opisnim terminima, na osnovi njih se može steći, makar djelomično, uvid u izložene radove. ${ }^{31}$

O izložbi u Somboru koja je uslijedila neposredno nakon novosadske, nema gotovo nikakvih podataka. Napori da se pronađe prikaz izložbe u lokalnom tisku za sada nisu urodili plodom. Jedino se u naslovu i uvodnoj rečenici već spomenutog rezimea koji je objavljen u Obzoru pominje Sombor, kao i u proglasu iz Novog doba koji su potpisali Miše i Studin, ${ }^{32}$ svakako vjerodostojnog s obzirom na to da su i sami bili sudionici. U novijoj literaturi na to upućuje jedino šturi zapis u Umetničkoj topografiji Sombora: ${ }^{33}$ "Umetnički život u Somboru posle prvog svetskog rata bio je prožet nizom različitih izložbi, pri čemu su izlagali umetnici iz Zagreba i Beograda." Među imenima se spominje i Jerolim Miše iz Zagreba, ali se ne navodi izložba na kojoj je izlagao.

\section{Stari Bečej, Novi Bečej, Senta, Velika Kikinda i Veliki Bečkerek, 1925.}

Starobečejski tjednik Novo vreme $e^{34}$ obavijestio je čitatelje da će Grupa nezavisnih umjetnika u nekim vojvođanskim gradovima, u prvom redu u njihovu mjestu, prirediti izložbu kiparskih i slikarskih radova. Izložbe se organiziraju na preporuku dr. Laze Popovića, »poznatog osnivača Sokola u Vojvodini«. ${ }^{35}$ Otvaranje izložbe prvobitno je bilo planirano za prvi dan Uskrsa, ali je odgođeno zbog angažmana umjetnika u uređenju paviljona Kraljevine Jugoslavije za Izložbu dekorativnih umjetnosti u Parizu, gdje su dvije Kršinićeve skulpture u drvetu dobile Grand Prix. Dalje, tekst najavljuje oko stotinu radova Ivana Meštrovića, Joze Kljakovića, Zlatka Šulentića, Jerolima Miše, Vladimira Varlaja, Frana Kršinića i Vladimira Becića - skupine u nešto izmijenjenom sastavu u odnosu na prethodnu godinu. U sljedećem broju Novog vremena $^{36}$ najavljuje svečano otvaranje izložbe u nedjelju, 3 . svibnja, govorom dr. Milana Popovića (vlasnika i urednika lista, vjerojatno i pisca tekstova o izložbi), te da su u prethodni petak u Bečej prispjeli Becić, Varlaj i Miše, kako bi rasporedili radove u »velikoj dvorani srpske središne škole«. Iste novine ${ }^{37}$ po zatvaranju izložbe izvještavaju o dobroj posjeti i komercijalnom efektu postave hrvatskih umjetnika koji "prikazuju nov moderniji pravac u slikarstvu. Oni ne pripadaju školi futurista, niti ekstremista, nego zastupaju slobodno, samostalno mišljenje.« Ovom se rečenicom završava svaki kritički prikaz izloženih radova, o kojima više saznajemo iz Kataloga otipkanog pisaćom mašinom, $s$ popisom radova i cijenama. ${ }^{38}$

Unatoč naporima da se identificira makar i jedan od radova koji su prodani na ovim izložbama grupe, u muzejima i privatnim zbirkama u Vojvodini nije ih bilo moguće pronaći. Kao dobar se putokaz pokazala fotografija snimljena u Senti

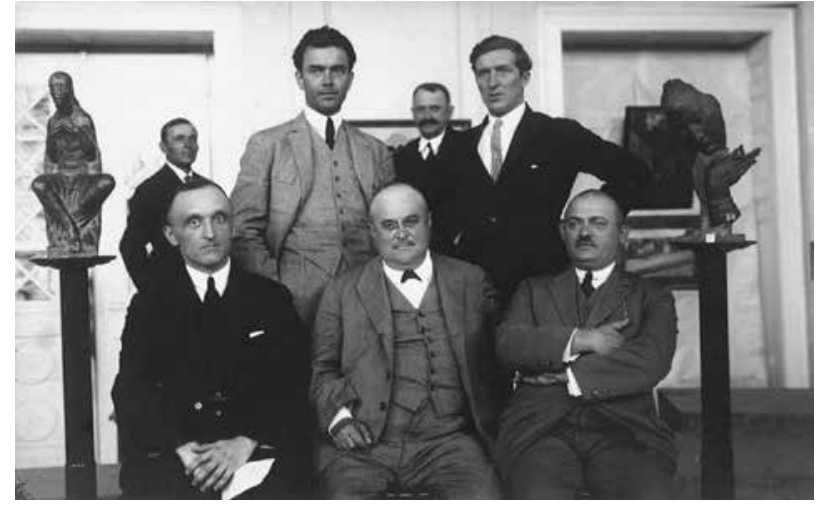

2. Varlaj i Miše s Jocom Vujićem i Urošem Džonićem prilikom otvaranja izložbe u Senti, 1925. (izvor: ANA ŠEPAROVIĆ, bilj. 12) / Varlaj and Miše with Joca Vujić and Uroš Džonić at the opening of the exhibition in Senta, 1925 (source: ANA ŠEPAROVIĆ, note 12)

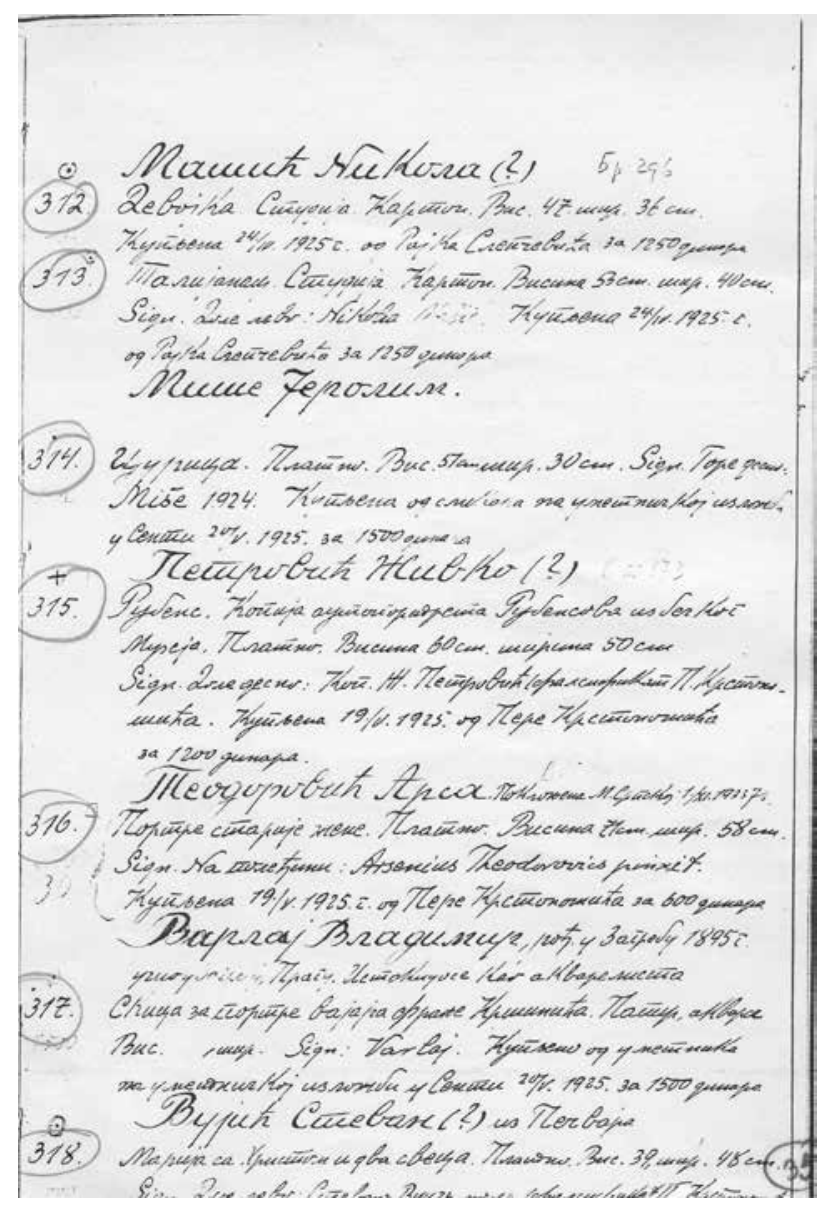

3. Inventarna knjiga Muzeja Joce Vujića u Senti (foto: Galerija Matice srpske, Novi Sad) / Inventory records of the Joca Vujic Museum in Senta (photo: Gallery of Matica srpska, Novi Sad)

prilikom otvaranja izložbe (sl. 2). ${ }^{39} \mathrm{U}$ prvom planu, među petoricom muškaraca sjede Jovan Vujić, veleposjednik i vlasnik muzeja iz Sente, i Uroš Đžonić, direktor Sveučilišne knjižnice u Beogradu, Vujićev potonji biograf i posrednik u poklanjanju muzejske zbirke beogradskom Sveučilištu. ${ }^{40}$ 


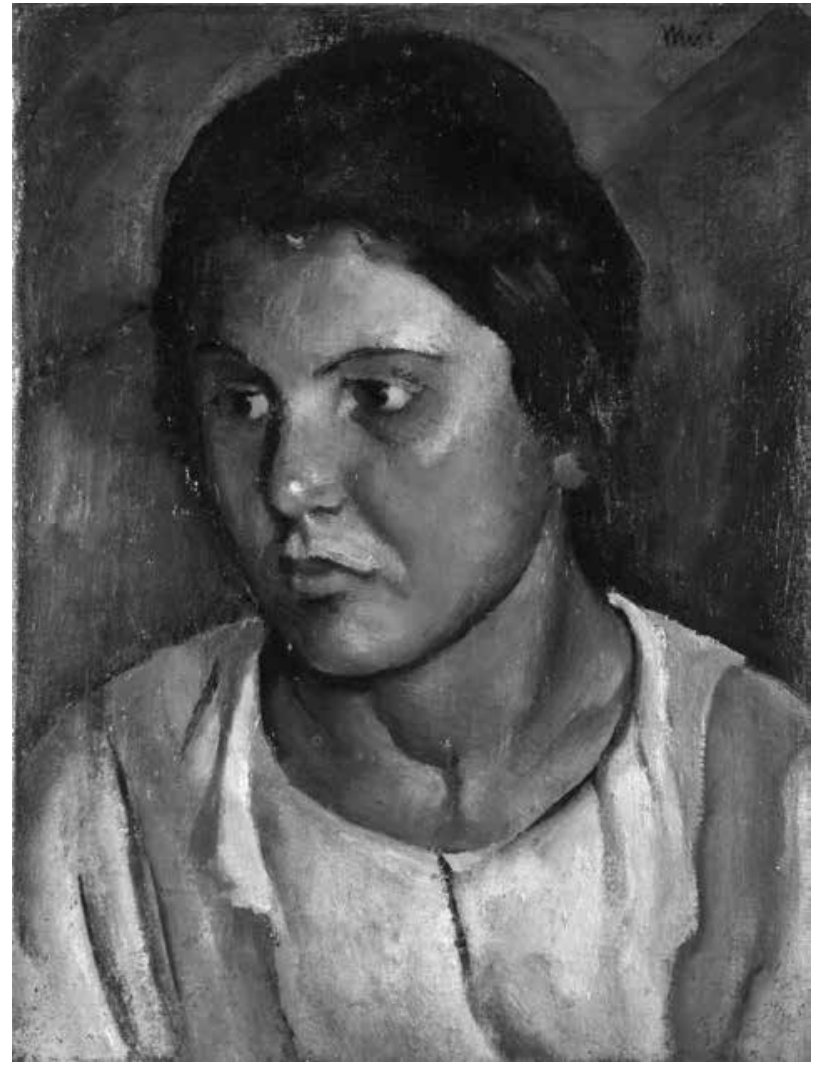

4. Jerolim Miše, Curica, Narodni muzej u Beogradu (foto:

Narodni muzej u Beogradu) / Jerolim Miše, Girl, National Museum in Belgrade (photo: National Museum in Belgrade)

Iza njih stoje Vladimir Varlaj i Jerolim Miše. U pozadini je skulptura Molitva Frana Kršinića, jedna od mnogih (umjetnikovih) verzija ove teme. Imajući u vidu kolekcionarsku strast Jovana Vujića, bilo je logično pretpostaviti kako je on otkupio bar neki od radova s izložbe u Senti, što se pokazalo točnim (sl. 3). U Narodnom muzeju u Beogradu nalaze se slike Curica Jerolima Miše (sl. 4) ${ }^{41}$ kao i Skica za portret kipara Frana Kršinića (sl. 5) ${ }^{42}$ Vladimira Varlaja, obje evidentirane u katalogu izložbe. O daljem tijeku turneje Grupe nezavisnih umjetnika 1925. godine nema pisanih tragova, fotografija ni identificiranih radova.

\section{Novi Sad, 1927.}

U lipnju 1927. godine u Novom Sadu je u povodu obilježavanja sto godina od preseljenja Matice srpske iz Pešte u Novi Sad u zgradi Trgovačke akademije otvorena Izložba starog srpskog slikarstva u Vojvodini, kao i VI. jugoslovenska umetnička izložba, posljednja u nizu izložbi ove vrste. Šestero umjetnika - Ljubo Babić, Vladimir Becić, Vladimir Varlaj, Ivan Meštrović, Jerolim Miše i Krsto Hegedušić, nastupilo

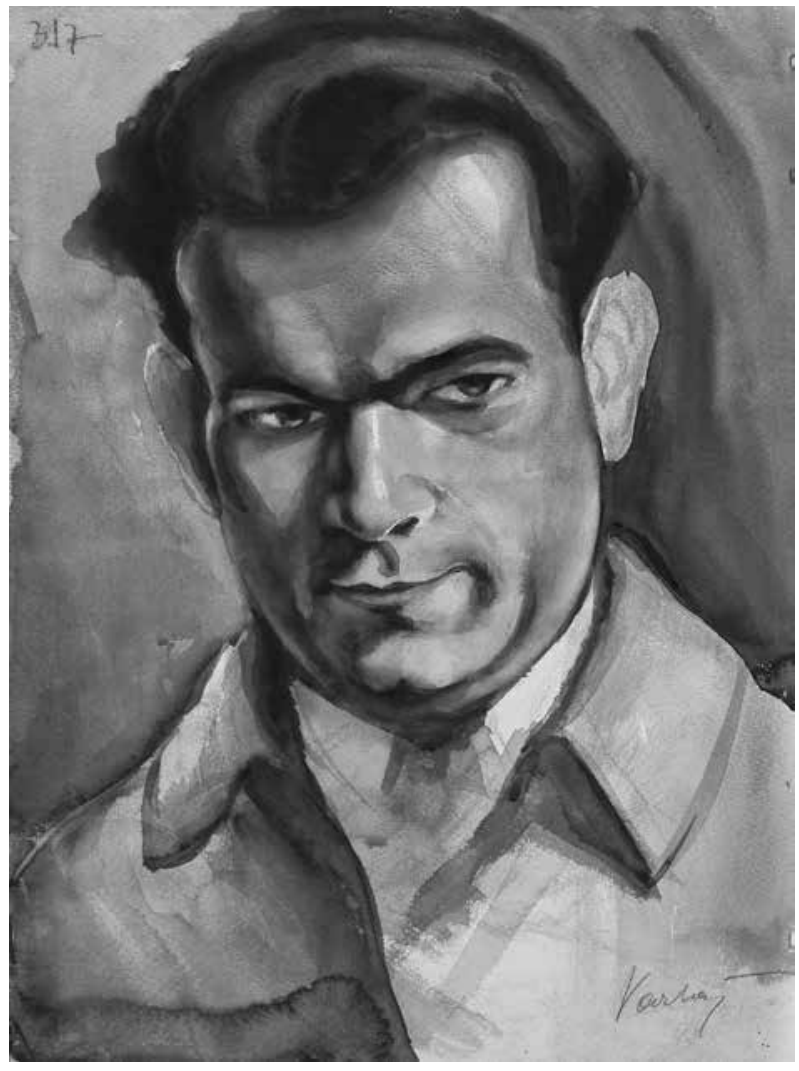

5. Vladimir Varlaj, Skica za portret kipara Frana Kršinića (foto: Narodni muzej u Beogradu) / Vladimir Varlaj, Sketch for the portrait of the sculptor Frano Kršinić (photo: National Museum in Belgrade)

je kao zasebna formacija pod nazivom Nezavisni Zagreb. ${ }^{43}$ Kao novo ime u grupi javlja se Krsto Hegedušić koji je, iste godine, zajedno s pripadnicima Grupe nezavisnih umjetnika sudjelovao na I. jugoslovenskoj izložbi grafike u Lawovu (Poljska). »(...) ipak bi bilo krajnje vreme (za) udruživanje snaga umetničkih s ove i one strane Save, Dunava i Drine $\mathrm{u}$ težnji da se u vaspitanje narodno unese i razvijanje kulta lepote (...). Novi Sad je dužan da u svojoj sredini stvori centar (među vojvođanskim Srbima) umetničko-slikarskovajarskog razvijanja, onako kao što to čine za književnost i dramsku umetnost i kao što su Hrvati stvorili u Zagrebu, kako bi se lakše i neposrednije razvio narodni kult a narodno vaspitanje podiglo na viši stupanj kulture. Razvijanje umetničkog osećanja za lepim potrebno je isto tako kao što je razvijena potreba za pismenost, ukus i naravi valja oblagorođavati, a to se može postići samo umetnošću«, pisala je u nedovršenom rukopisu Nadežda Petrović 1909., skicirajući osvrt na Prvu dalmatinsku umjetničku izložbu održanu u Splitu 1908. godine. ${ }^{44}$ Pod dojmom izložbe koju je posjetila krajem rujna, ona je gradu s najstarijim kazalištem u regiji i bogatim književnim životom poželjela aktivnu ulogu i u oblasti koja je početkom 20. stoljeća bila zapostavljena - vizualnim umjetnostima. Dogodilo se da je Novi Sad 
domaćin posljednjoj jugoslavenskoj izložbi, manifestaciji čiji je osnivač, 1904., Nadežda Petrović bila i za kakve se do kraja života zalagala. Zamišljene kao plod južnoslavenskoga kulturnog ujedinjenja, jugoslavenske umjetničke izložbe su od samog početka nosile u sebi obilježje političkih prilika koje su utjecale na odnose u umjetničkoj praksi. Poslije beogradske izložbe 1922. izgubio se interes za takvu vrstu okupljanja, da bi od 1928. otpočeo ciklus Prolećnih izložbi slikarskih i vajarskih radova jugoslovenskih umetnika, gdje je izlagačka politika bila podređena ponajprije estetičkim, a ne političkim mjerilima. »U martu 1927. godine uvaženi krug novosadske kulturne javnosti, ispitujući mogućnosti i vidove proslave Matice srpske, zalagao se da se tim povodom održi izložba hrvatske umetnosti. ${ }^{45} \mathrm{Na}$ inicijativu Mihaila S. Petrova u posljednjem je trenutku odlučeno da izložba dobije jugoslavenski karakter te da okupi različite umjetnike kao i veći broj umjetničkih grupa. Pored prilično slabog odjeka izložbe u tisku, posebno ljubljanskom i sarajevskom, zagrebačke su novine reagirale na dotad neuobičajen način. ${ }^{46}$ Najpotpunije kritičko razmatranje umjetničkih dometa izložbe dao je Milan Kašanin ${ }^{47}$ koji je s dužnom pozornošću popratio i nastup pripadnika Grupe nezavisnih umjetnika. Predstavio ih je kao »malu, ali značajnu i kompaktnu grupu « koju karakterizira nešto »borbeno i oporo «. Iz konteksta izdvaja Becića, čiju Nature morte ubraja među najbolje slike na izložbi, dok kvalitetu u slici Ljube Babića nalazi prije u ideji i programu nego u slikarskoj vrijednosti. Pejzaže Vladimira Varlaja ocjenjuje veoma pozitivno, a Miši prebacuje da njegove ambicije premašuju slikarsko znanje. U najuspješnije izlagače grupe svrstava Hegedušića i Ivana Meštrovića koji »ima misli, osećanja, snage i izraza «, a najbolji izlagači uopće za njega su predstavnici Proljetnog salona i grupe Oblik.

$$
* * *
$$

Razdoblje aktivnosti Grupe nezavisnih umjetnika predstavlja veoma dinamično vrijeme na jugoslavenskoj umjetničkoj sceni, istodobno posebno zanimljivo kada je riječ o interakciji zagrebačke i vojvođanske kulturne scene. Pored već spomenute grupe Oblik koja je svoje djelovanje započela u Novom Sadu (1927.), treba upozoriti i na praksu Proljetnog salona u predstavljanju u drugim kulturnim okruženjima, što je krajem 1924. i početkom 1925. godine rezultiralo i izložbama u Novom Sadu, Subotici i Somboru, ${ }^{48}$ koje su imale znatnog odjeka u javnosti. ${ }^{49}$ Također, usporedno s formiranjem Grupe nezavisnih umjetnika odvijaju se i nastupi avangardnih grupa, dadaista na čelu s Draganom Aleksićem i mađarskih aktivista, od matineja u Novom Sadu u lipnju 1922. godine, preko Vinkovaca i Osijeka, do posljednje i ujedno najveličanstvenije dada-manifestacije u Subotici $\mathrm{u}$ studenome iste godine. ${ }^{50}$ Imajući sve to na umu, može se zaključiti da potreba za stvaranjem umjetničkih grupa u razdoblju između dva svjetska rata, kao i inzistiranje na njihovoj mobilnosti i komunikativnosti sa što širim slojem publike, predstavlja svojevrstan fenomen epohe i neophodno ga je promatrati u daleko širem kontekstu nego što je to rad samo jedne od njih, ovog puta Grupe nezavisnih umjetnika.

\section{BILJEŠKE}

1 JASNA JOVANOV, The »Oblik« Art Group, 1926-39, u: On the Very Edge: Modernism and Modernity in the Arts and Architecture of Interwar Serbia (191-1941), (ur.) Jelena Bogdanović, Lilien Filipovitch Robinson, Igor Marjanovic, Leuven University Press, Leuven, 2014., 97-115.

$2 \mathrm{Na}$ ideju da istražim djelovanje Grupe nezavisnih umjetnika u Beogradu i Vojvodini potaknuo me tekst dr. sc. Frane Dulibića: FRANO DULIBIĆ, Grupa nezavisnih umjetnika (1921.-1927.), Radovi Instituta za povijest umjetnosti, 23 (1999.), 199-208. Prema njegovoj formulaciji usvojen je i naziv grupe koju tisak oslovljava različitim imenima (Grupa nezavisnih, Nezavisna grupa, Grupa hrvatskih nezavisnih umjetnika, Grupa slobodnih umjetnika itd.). Profesoru Dulibiću zahvaljujem i na podacima o dokumentima korisnim za pisanje rada, kao i dr. sc. Ani Šeparović koja mi je dala mnoge značajne informacije te omogućila pristup dokumentima i tekstovima iz hrvatskog tiska. Vidi također: FRANO DULIBIĆ, Slikarstvo Vladimira Varlaja, Institut za povijest umjetnosti, Zagreb, 2011., 151-152, 163-164, 169-171.

3 JEROLIM MIŠE, MARIN STUDIN, Izjava Nezavisne grupe, Novo doba, 234 (8. studenoga 1924.), 4.

4 CRITICUS (FRANJO DEAK), Hrvatstvo i umjetnost, Hrvatska riječ, 145 (1924.); prema: FRANO DULIBIĆ (bilj. 2, 1999.), 201.

5 FRANO DULIBIĆ (bilj. 2, 1999.), 201.

6 FRANO DULIBIĆ (bilj. 2, 1999.), 205.

7 SLAVKO BATUŠIĆ, Pola vijeka hrvatskog slikarstva (Slikarstvo zagrebačkog središta), u: Pola vijeka jugoslavenskog slikarstva, Moderna galerija, Zagreb, 1953., LVII.

8 SLAVKO BATUŠIĆ (bilj. 7), LVII.

9 Citirano prema: FRANO DULIBIĆ (bilj. 2, 1999.), 204.

$10 \mathrm{Na}$ ove greške i Ljubu Babića kao izvor pogrešnih podatka upozoreno je u: FRANO DULIBIĆ (bilj. 2, 1999.). Vjerojatno zbog samog Babića kao izvora, greška se ponavlja u: IVANKA REBERSKI, Realizmi dvadesetih godina u hrvatskom slikarstvu, Institut za povijest umjetnosti, ArTresor studio, Zagreb, 1997., 280; Ljubo Babić, antologija, katalog izložbe, (ur.) Ivanka Reberski, Libuše Jirsak, Moderna galerija, Zagreb, 2010., 259, 262.

11 -, Nezavisna grupa, Hrvatska riječ, prilog: Ars Croatica, 139 (1924.), 3; Ars croatica, Izložba grupe hrvatskih nezavisnih umjetnika u Splitu, Jutarnji list, 13/4560 (10. listopada 1924.), 7. FRANO DULIBIĆ (bilj. 2, 1999.), 203.

12 Razmatranja o ulozi Jerolima Miše u formiranju Grupe nezavisnih umjetnika i formuliranju ciljeva i strategije grupe izložena su kao interpretacija ove teme: ANA ŠEPAROVIĆ, Jerolim Miše (1890-1970) u hrvatskome slikarstvu i likovnoj kritici, doktorska disertacija, Zagreb, 2014., 156-159.

13 FRANO DULIBIĆ (bilj. 2, 1999.), 199, 202, 204.

14 VLADIMIR LUNAČEK, Iz našeg umjetničkog svijeta, Obzor, LXIV/310 (1923.), 1-2. Tekst je prepoznat kao jedan od mogućih poticaja radu grupe. FRANO DULIBIĆ (bilj. 2, 1999.), 200, 207. "No s obzirom na to da Nezavisni izlažu po provinciji već od 1921. godine, a Mišini tekstovi u kojima govori o potrebi kulturnoga oživljavanja periferije datiraju iz 1920. i 1921. godine, ne treba zanemariti mogućnost da je prvi poticaj dao upravo Miše.« Prema: ANA ŠEPAROVIĆ (bilj. 12), 156.

15 -, Nezavisna grupa, Hrvatska riječ, prilog: Ars Croatica, 139 (1924.), 3 . 
16 JEROLIM MIŠE, O mlađima u našoj likovnoj umjetnosti, Savremenik, 6 (1920.), 175.

17 JEROLIM MIŠE, Naša likovna umetnost, Književna republika, 4 (1924.), 163.

18 O Petru Dobroviću: SIMONA ČUPIĆ, Petar Dobrović, Prosveta, Beograd, 2003.

19 5. jugoslovenska umetnička izložba, katalog izložbe, Beograd, 1922., 26, 36-37.

20 FRANO DULIBIĆ (bilj. 2, 1999.), 206.

21 Dokumentarni fond Spomen-zbirke Pavla Beljanskog, Novi Sad, inv. br. D 3756.

22 5. jugoslovenska umetnička izložba (bilj. 19), 36.

23 Ibid, 26.

24 MOMČILO SELESKOVIĆ, Povodom Pete jugoslovenske izložbe, Republika, 25. lipnja 1922.; 2., 6., 9., 13., 16. srpnja 1922. Prema: DRAGUTIN TOŠIĆ, Jugoslovenske umetničke izložbe 1904-1927., Institut za istoriju umetnosti, Beograd, 1983., 225.

25 TODOR MANOJLOVIĆ, Peta jugoslovenska umetnička izložba, Misao, knj. IX, sv. 5, 6 (1922.), 1064-1073. Prema: TODOR MANOJLOVIĆ, Likovna kritika, (ur.) Jasna Jovanov, Gradska narodna biblioteka, Zrenjanin, 2007., 63-80.

26 E. NADVORNIK, Jugoslovenska umetnička izložba, Vreme, 16. lipnja 1922. Prema: DRAGUTIN TOŠIĆ (bilj. 24), 140.

27 V., Izložba grupe slobodnih umetnika, Zastava, 27. svibnja 1924., 2.

28 (p.), Horvát müveszék kiállitása a Városházán, Délbácska, 142 (27. május 1924.), 5, 6; Ž., Umetnička izložba u Novom Sadu, Jedinstvo, 28. svibnja 1924.

29 -, Obaveštenje o izložbi u Novom Sadu, Vidovdan, III/48 (1924.), 2.

30 -, Dvije izložbe zagrebačkih umjetnika u Novom Sadu i Somboru, Obzor, LXV/159 (1924.), 2.

$31 \mathrm{Na}$ osnovi tekstova moguće je identificirati oko trećinu radova. Ljubo Babić je izložio Lido, Scuola di San Rocco, Piazza, Gruž, terasa, Autoportret, Portret pjevačice; Jozo Kljaković: Pastir, Uskrsnuće Lazarevo, Glava Krista, Glava Madone, Akt, Satir i Nimfa, Suzana; Jerolim Miše: Dama, Virtuoz, Dijete, Dvije prijateljice, Mladić s naočalama, Splitska; Zlatko Šulentić: Podne, Lutke; Vladimir Varlaj: Hvar, Korčulanska obala, Dubrovnik, nekoliko snježnih pejzaža i tri starogradske vedute; Marin Studin: Prorok, Madona, Reljef drvo, Studija; Frano Krišinić: Orijentalac, Sjećanje, Albanski križevi, Oslobođenje, Zrelo voće, Zora, Proleteri, Dobrovoljac, Objava rata. Napomena: Neki su nazivi slika navedeni u slobodnom prijevodu s mađarskog jezika (iz teksta u dnevnim novimama Délbácska). 32 JEROLIM MIŠE, MARIN STUDIN (bilj. 3), 4.

33 PAVLE VASIĆ, Umetnička topografija Sombora, Matica srpska, Novi Sad, 1984., 156.

34 -, Slikarska izložba u Starom Bečeju, Novo vreme, 26. travnja 1925., 2. 35 Dr. Laza Popović (Srijemski Karlovci, 1877. - Beograd, 1945.), liječnik, organizator sportskih aktivnosti i društveni radnik, medicinu je studirao u Beču. U Srijemskim Karlovcima 1904. osniva Sokolsko društvo, organizira sudjelovanje sokolskih društava na sportskim manifestacijama, a osnivač je i prvoga Jugoslavenskog sokolskog društva 1919. godine. Zbog političkih ideja, prije 1914. nekoliko se puta našao na optuženičkoj klupi (1910. ili 1914. kada mu je bečko sveučilište oduzeo diplomu koju je ponovno dobio u Pragu 1918.). Krajem 1918. stječe zvanje primarijusa i mjesto upravitelja rendgenskog laboratorija Zakladne bolnice u Zagrebu. Kao profesor rendgenologije u Kraljevini Jugoslaviji, na Medicinskom fakultetu zagrebačkog Sveučilišta 1921. izabran je za izvanrednog profesora, kao i za prvog predsjednika Društva za rendge- nologiju, osnovanog u Zagrebu 1927. S Milanom Ćurčinom i Markom Kostrenčićem uređivao je časopis Nova Evropa koji je izlazio u Zagrebu; uredio je Srpske narodne pesme (izdanje zagrebačkog knjižničara Veljka Vasića). Također je uređivao izdanja sokolskih društava. Prije kraja života dobiva zvanje senatora Kraljevine Jugoslavije.

36 -, Slikarska izložba, Novo vreme, 3. svibnja 1925., 2.

37 POSMATRAČ, Dve izložbe, Novo vreme, 10. svibnja 1925., 2.

38 Katalog izložbi Grupe nezavisnih umjetnika u Starom Bečeju, Senti, Velikoj Kikindi, Novom Bečeju, Velikom Bečkereku, svibanj-lipanj 1925.; Arhiv za likovne umjetnosti Jugoslavenske akademije, 189a.

39 FRANO DULIBIĆ (bilj. 2, 2011.), 152. Na fotografiju mi je pozornost skrenula dr. sc. Ana Šeparović, na čemu sam joj veoma zahvalna.

40 Jovan Vujić (Senta, 1863. - Beograd, 1934.), veleposjednik, narodni poslanik, javni radnik i dobročinitelj, kolekcionar koji je sakupio kapitalna djela srpske umjetnosti od 18. stoljeća do suvremenog doba i bogatu zbirku raritetnih knjiga. Slike iz kolekcije Jovana Vujića čine okosnicu knjige Veljka Petrovića Srpska umetnost u Vojvodini (Matica srpska, 1927.). Kolekciju je vodio kao fond Muzeja Joce Vujića u Senti, da bi je većim dijelom, početkom četvrtog desetljeća 20. stoljeća, poklonio beogradskom Sveučilištu i Matici srpskoj. Dio kolekcije koji je pripao Sveučilištu stradao je u bombardiranju tijekom Drugoga svjetskog rata, a potom je dodijeljen Narodnom muzeju u Beogradu. I Narodni muzej i Matica (a potom i Galerija Matice srpske) nakon Drugoga svjetskog rata otkupljivali su slike, crteže, skulpture i gravure iz ostavštine Jovana Vujića, tako da se u njihovim fondovima danas nalaze 444 djela. Vidi: LEPOSAVA ŠELMIĆ, Zbirka Jove Vujića, Narodni muzej, Galerija Matice srpske, Novi Sad-Beograd, 1989.

41 Jerolim Miše, Curica, ulje na platnu, $41,5 \times 31 \mathrm{~cm}$; potpisano gore desno: Miše 24. NM JV 30. LEPOSAVA ŠELMIĆ (bilj. 40), 74, kat. br. 249.

42 Vladimir Varlaj, Skica za portret kipara Frana Kršinića, akvarel, 43,3 $\times 32,6 \mathrm{~cm}$; potpisano desno dolje: Varlaj. NM JV 145. LEPOSAVA ŠELMIĆ (bilj. 40), 48, kat. br. 49.

43 Izložba starog srpskog slikarstva u Vojvodini i VI. jugoslovenska umetnička izložba, katalog izložbe, Novi Sad, 1927., 73-74.

44 DRAGUTIN TOŠIĆ (bilj. 24), 146. U dogovorima o organiziranju izložbe sudjelovali su, između ostalih, dr. Laza Popović, Todor Manojlović, Vasa Stajić, kao i Ivan Meštrović i njegov prijatelj, novosadski liječnik dr. Joca Nenadović. KATARINA PAVLOVIĆ, Šesta jugoslovenska umetnička izložba u Novom Sadu, Zbornik za likovne umetnosti Matice srpske, 10 (1974.), 394.

45 DRAGUTIN TOŠIĆ (bilj. 24), 147.

46 Popis izlagača po grupama i udruženjima, bez ikakvog komentara, objavljen je u reviji Umjetnost, Zagreb-Beograd-Ljubljana, sv. IV i V (1927.). »Tek više meseci posle zatvaranja izložbe javiće se na stranicama Obzora članak anonimnog autora koji, ne mogavši da prećuti lično nezadovoljstvo, naziva celokupnu kritiku izložbe stendencioznom`a izložbu priredbom `bezikakvog moralnog i materijalnog efektar.» A. A., Šesta jugoslovenska umjetnička izložba u Novom Sadu, Obzor, 4. studenoga 1927. Prema: KATARINA PAVLOVIĆ (bilj. 44), 405.

47 MILAN KAŠANIN, Šesta jugoslovenska umetnička izložba, Srpski književni glasnik, 21/7 (1927.), 532-533.

48 PETAR PRELOG, Proljetni salon 1916-1928., katalog izložbe, Umjetnički paviljon, Zagreb, 2007., 112.

49 Slikarstvo u Vojvodini 1900-1944, (ur.) Slobodan Sanader, Galerija savremene likovne umetnosti, Novi Sad, 1991., 205.

50 JASNA JOVANOV, Demistifikacija apokrifa, Apostrof, Novi Sad, 1999., 67-70. 
Summary

Jasna Jovanov

Exhibitions of the Independent Artists Group in Vojvodina 1924-1925

The activity of the Independent Artists Group between 1921 and 1927 consisted mainly of participating in group exhibitions or of individual exhibitions of the majority of group members. The Group insisted on exhibiting their works in places outside major artistic centres of the Kingdom of Yugoslavia, especially in Croatia and in Vojvodina. In the course of 1924 and 1925 the Group organized two series of exhibitions, first in Novi Sad and Sombor, and then in Stari Bečej, Novi Bečej, Senta, Velika Kikinda (Kikinda) and Veliki Beckerek (Zrenjanin). The Independent Artists Group also participated in the $5^{\text {th }}$ Yugoslav Art Exhibition (Vjugoslovenska umetnička izložba) in Belgrade, where they exhibited alongside artists of the Spring Salon (Proljetni salon), as well as in Novi Sad in the $6^{\text {th }}$ Yugoslav Art Exhibition (VI jugoslovenska umetnicka izložba), which was their last exhibition. Members of the group changed, so that all exhibitions in question included the works of Jerolim Miše and Vladimir Varlaj, and some of them the works of Ljubo Babić, Jozo Kljaković, Zlatko Šulentić, Frano Kršinić, Marin Studin, Ivan Meštrović, Vladimir Becić and Krsto Hegedušić. The Independent Artists Group represents one of the artistic collectives active during the interwar period, brought together solely on the basis of artistic criteria. Furthermore, incited by the ideas of de-metropolisation of art, of bringing culture closer to wider public in light of the influence of post-revolutionary Russia, as well as by the intention to exert a commercial effect, the Group started the aforementioned series of travelling exhibitions. New findings enabled the identification of Jeronim Miše as the ideator of the said process, while the research of archival documents and media coverage permitted the analysis of these exhibitions and the attempt of identifying the exhibited works, as well as an inquiry into the afterlife of sold paintings. 